\title{
Institutional infrastructure and economic growth in member countries of the Organization of Islamic Cooperation (OIC)
}

\begin{abstract}
This paper examines the relationship between the quality of different dimensions of institutional infrastructure and economic growth in a panel of 39 member countries of the Organization of Islamic Cooperation (OIC). The empirical results confirm that better-quality political and economic institutions can have positive effects on economic growth. All in all, the evidence from nonlinear model reveals that the quality of political institutions that ensure stable government, less expropriation, and low external conflict are the core dimensions of an institutional matrix because they influence the growth effects of economic institutions, confirming the ñhierarchy of institutions hypothesis.ò The study also finds that when political and economic institutions are accounted for, institutions that prevent internal conflict and tensions arising from ethnic and religious conflicts do not have significant (positive) impacts on growth. Thus, institutional reforms to upgrade the quality of both political and economic institutions are crucial for development in OIC countries.
\end{abstract}

Keyword: Conflict-preventing institutions; Dynamic panel threshold model; Economic growth; Economic institutions; Organization of Islamic Cooperation; Political institutions 